\title{
IDENTIFIKASI METABOLIT SEKUNDER DAN AKTIVITAS ANTIBAKTERI EKSTRAK DAUN SUNGKAI (Peronema canescens JACK.) TERHADAP BEBERAPA BAKTERI PATOGEN
}

\author{
Arsyik Ibrahim ${ }^{1)}$ dan Hadi Kuncoro ${ }^{2)}$ \\ Bagian Biologi-Mikrobiologi Farmasi, Fakultas Farmasi, Universitas Mulawarman, \\ Samarinda, Kalimantan Timur ${ }^{1)}$ \\ Laboratorium Penelitian FARMAKA TROPIS Fakultas Farmasi, Universitas Mulawarman, \\ Samarinda, Kalimantan Timur ${ }^{2}$ \\ email : achie.ibrahim@gmail.com
}

\begin{abstract}
A research which identification of secondary metabolites and antibacterial activity test from methanol exstract of leaf Sungkai (Peronema canencens Jack) to several pathogens bacterial, which aims to identification of secondary methabolites and determine the antibacterial activity from crude methanol extract of leaf Sungkai (P. canencens Jack). against Streptococcus mutans, Salmonella thyposa, Bacillus subtilis and Staphylococcus aureus bacteria. Material test obtained by maceration with methanol, then tested for activity. Minimum Inhibition Concentration (MIC) value extract was determined by liquid dilution and the followed by scratches on solid media method. Minimum Kill Concentration (KBM) value extracts was determined by agar diffusion method with using paper disks.The results secondary metabolite identify form extracts of leaves $P$. canencens obtainable derived alkaloid, terpenoids steroids, flavonoids, and tannin compounds. Methanol extract have the antibacterial activity. Minimum Inhibition Concentration (MIC) value of extract is concentration of $20 \%$ for bacteria S. mutans, S.thiposa and S.aureus, while for the B. subtilis is konsentration of $15 \%$. Minimum Kill Concentration (KBM) values exstract at a concentration of 5\% effective at killing S. mutans and S. thyposa bacteria, while the concentration of $1 \%$ effective to bacteria B.subtilis and S.aureus.
\end{abstract}

Key words: P. canencens Jack, antibacteria activity, S. mutans, S. thiposa, B. subtillis, S. aureus

\begin{abstract}
ABSTRAK
Telah dilakukan penelitian identifikasi metabolit sekunder dan aktivitas antibakteri ekstrak metanol daun Sungkai (P.canencens Jack) terhadap beberapa bakteri patogen. Penelitian ini bertujuan untuk mengidentifikasi metabolit sekunder dan mengetahui aktifitas antibakteri dan Kadar Hambat Minimum (KHM) dan Nilai Kadar Bunuh Minimum (KBM) ekstrak kasar metanol daun Sungkai (P.canencens Jack.) terhadap bakteri Streptococcus mutans, Salmonella thyposa, Bacillus subtilis dan Staphylococcus aureus. Bahan uji diperoleh dengan maserasi daun sungkai dengan metanol, selanjutnya diuji aktivitasnya. Nilai Kadar Hambat Minumum (KHM) ekstrak ditentukan dengan metode dilusi cair dan dilanjutkan dengan metode goresan pada media padat. Nilai Kadar Bunuh Minimum (KBM) ekstrak ditentukan dengan metode difusi agar padat menggunakan paper disk. Hasil penelitian identifikasi metabolit sekunder ekstrak $P$. canencens diperoleh golongan senyawa alkaloid, terpenoid -


Identifikasi metabolit sekunder dan aktivitas antibakteri ekstrak daun sungkai (Peronema canescens jack.) Terhadap beberapa bakteri patogen

steroid, flavanoid, dan tanin. Ekstrak metanol daun $P$. canencens Jack. memiliki aktifitas sebagai antibakteri. Nilai KHM ekstrak P. canencens untuk bakteri S..mutans, S.thiposa dan S.aureus adalah konsentrasi $20 \%$, sedangkan untuk bakteri B. subtilis adalah $15 \%$. Nilai KBM ekstrak metanol $P$. canencens pada konsentrasi $5 \%$ efektif membunuh bakteri S.. mutans dan S. thyposa, sedangkan konsentrasi $1 \%$ efektif membunuh bakteri B.subtilis dan S.aureus.

Kata kunci : P. canencens Jack, Aktivitas antibakteri, S. mutans, S. thyposa, B. subtillis, S. aureus

\section{PENDAHULUAN}

Sejarah perkembangan farmasi, tumbuhan obat merupakan sumber senyawa bioaktif yang berkhasiat mengobati berbagai jenis penyakit. Hingga saat ini, sumber alam nabati masih tetap merupakan sumber bahan kimia baru yang tidak terbatas, baik senyawa isolasi murni yang dipakai langsung (Sinambela, 2002).

Saat ini penyakit infeksi masih menjadi masalah serius di Indonesia, ditambah lagi dengan semakin meluasnya resistensi mikroba terhadap obat-obatan antibiotika yang telah tersedia. Hal tersebut mendorong pentingnya penggalian sumber obat-obatan antimikroba lain dari bahan alam.

Tanaman obat tradisional diketahui potensial untuk dikembangkan lebih lanjut pada pengobatan penyakit infeksi, namun masih banyak yang belum dibuktikan bioaktivitasnya secara ilmiah (Hertiani, 2003). Salah satu tumbuhan obat yang banyak tumbuh di Indonesia yang banyak dimanfaatkan adalah tumbuhan Sungkai $(P$. canescens. Jack).

Pada suku Dayak di Kalimantan Timur sampai saat ini masih tetap mempertahankan tradisi dengan memanfaatkan tumbuhan disekitarnya untuk pengobatan ataupun perawatan kesehatan misalnya tumbuhan Sungkai $(P$. canescens. Jack) suku verbenaceae pada bagian daun muda digunakan sebagai obat pilek, demam, obat cacingan (ringworms), dijadikan mandian bagi wanita selepas bersalin dan sebagai obat kumur pencegah sakit gigi (Mardi, 2010).

Pencarian senyawa selalu dibarengi dengan uji aktivitas (bioassay guided isolation) sehingga hasil penelitian yang dihasilkan memiliki kemanfaatan bagi pengembangan ilmu pengetahuan dan obat dari bahan alam, hal ini membuka kemungkinan perluasan penelitian tumbuhan/tanaman obat yang berasal dari daerah lain, termasuk Kalimantan Timur yang sumberdaya hayatinya belum dikembangkan dan dimanfaatkan secara optimal. Berdasarkan uraian tersebut, maka perlu dilakukan penelitian untuk tujuan penguatan kajian ilmiah dan pengembangan ilmu pengetahuan khususnya pemanfaatan bahan alam sebagai sumber obat baru.

Penelitian ini bertujuan untuk mengidentifikasi metabolit sekunder dan mengetahui aktifitas antibakteri dan Kadar Hambat Minimum (KHM) dan Nilai Kadar Bunuh Minimum (KBM) ekstrak metanol daun Sungkai (P.canencens Jack.) terhadap bakteri Streptococcus mutans, Salmonella thyposa, Bacillus subtilis dan Staphylococcus aureus. 
Identifikasi metabolit sekunder dan aktivitas antibakteri ekstrak daun sungkai (Peronema canescens jack.) Terhadap beberapa bakteri patogen

\section{METODE}

\section{Bahan tumbuhan.}

Daun $P$. canencens Jack, metanol teknis, medium Nutrien Broth (NB), Nutrien Agar (NA), Dimetil Sulfooksida (DMSO), $\mathrm{NaCl}$ fisiologis $0,9 \%$ pelarut organik teknis antara lain metanol, kloroform dan alkohol.

\section{Biakan Mikroba Uji.}

Strain Streptococcus mutans, Salmonella thyposa, Basillus subtilis, dan Staphylococcus aureus.

\section{Alat-alat yang digunakan.}

Batang pengaduk, bejana maserasi, botol pengencer, botol semprot, cawan Petri, chamber, corong, drigle sky, gelas kimia $250 \mathrm{~mL}$, gelas ukur 10,50 dan $100 \mathrm{~mL}$, inkubator, labu erlenmeyer $500 \mathrm{~mL}$, labu tentukur $50 \mathrm{~mL}$, Laminar Air Flow (LAF), lampu spiritus, autoklaf, oven, rotavapor, tabung reaksi, timbangan analitik, timbangan kasar, vortex mixer.

\section{Pengolahan dan ekstraksi.}

Daun P.canencens yang telah dikumpulkan dibersihkan dan dicuci dengan air, setelah dipisahkan bagian yang tidak diperlukan, kemudian dikeringkan dengan menggunakan oven suhu $40^{\circ} \mathrm{C}$ hingga bobot kering konstan. Daun yang telah kering kemudian dipotong-potong kecil untuk siap digunakan sebagai bahan penelitian.

\section{Ekstraksi sampel.}

Sebanyak 1100 g daun P.canencens kering, di serbukkan, kemudian diekstraksi secara maserasi menggunakan cairan penyari metanol. Filtrat disaring dan residu direndam lagi dalam pelarut yang sama selama 3 x 24 jam. Filtrat dikumpulkan dan diuapkan menggunakan rotavapor hingga diperoleh ekstrak metanol kering. Ekstrak metanol kering yang diperoleh sebanyak 53,632 g, ekstrak yang digunaklan untuk penelitian sebanyak 25 gram.

\section{Identifikasi Metabolit Sekunder Ekstrak.}

Identifikasi kandungan golongan metabolit dilakukan dengan menggunakan pereaksi kimia spesifik. Reaksi dinyatakan positif mengandung golongan senyawa metabolit sekunder tertentu, jika terjadi perubahan warna pada larutan pada saat penambahan pereaksi atau terdapat pengendapan disebabkan terjadinya reaksi. (Depkes RI, 2000)

\section{Pengujian aktivitas antimikroba.}

Ekstrak metanol daun $P$. canencens kering diuji aktivitasnya terhadap beberapa mikroba uji dengan metode dilusi cair dan dilusi padat untuk mengetahui nilai Kadar Hambat Minimum (KHM) ekstrak, dan selanjutnya dilakukan pengujian penentuan Kadar Bunuh Minimum (KBM) ekstrak menggunakan metode difusi agar padat menggunakan kertas paper disk. Medium - medium uji selanjutnya diinkubasi suhu $37^{\circ} \mathrm{C}$ selama 24 jam dalam inkubator. Pengamatan KHM ekstrak berdasarkan terbentuknya koloni keruh atau transparan pada permukaan medium uji. Pengamatan KBM ekstrak berdasarkan zona bening/bunuh disekeliling papaer disk. (Djiede, 2008)

\section{Penafsiran Hasil Penelitian.}

Konsentrasi minimal ekstrak metanol daun $P$. canencens yang menghambat pertumbuhan bakteri uji merupakan nilai Kadar Hambat Minimumnya (KHM), 
Identifikasi metabolit sekunder dan aktivitas antibakteri ekstrak daun sungkai (Peronema canescens jack.) Terhadap beberapa bakteri patogen

Konsentrasi minimal ekstrak yang membunuh mikroba uji (memberikan zona bening disekeliling paper disk) merupakan Kadar Bunuh Minimumnya (KBM).

\section{Analisis Hasil.}

Analisis data akhir dari aktivitas ekstrak metanol daun $P$. canencens menggunakan metode deskriptif-kualitatif berdasarkan kekeruhan medium dan aktivitas penghambatan pertumbuhan bakteri dan deskriptif-kuantitatif berdasarkan diameter zona bening atau zona bunuh terhadap bakteri uji dari masing-masing konsentrasi ekstrak uji.

\section{HASIL DAN PEMBAHASAN}

\section{Ekstraksi Sampel}

Sampel uji sebanyak 1100 gram dan diekstraksi dengan metode maserasi dengan pelarut metanol sebanyak 10 liter selama 3x24 jam dan sesekali diaduk. Pelarut metanol digunakan karena bersifat semi polar dimana pelarut ini memiliki kemampuan menyari kelompok senyawa polar dan senyawa non polar. Ekstrak cair hasil maserasi yang diperoleh kemudian dipekatkan dengan rotary evaporator sehingga diperoleh ekstrak kental dan untuk memperoleh penguapan yang maksimum sisa pelarut diuapkan dengan water bath sehingga diperoleh ekstrak kering sebanyak 53,632 gram. Ekstrak metanol yang diperoleh selanjutnya digunakan sebagai sampel uji penelitian. Jumlah ekstrak daun Sungkai dapat dilihat pada Tabel 1.

\section{Metabolit Sekunder Ekstrak Metanol}

Identifikasi metabolit sekunder ekstrak dilakukan terhadap ekstrak metanol, tujuan identifikasi adalah untuk mengetahui golongan - golongan metabolit sekunder yang terdapat dalam ekstrak kasar metanol. Hasil identifikasi golongan metabolit sekunder ekstrak metanol daun sungkai teridentifikasi golongan metabolit sekunder alkaloid, flavanoid , terpenoid-steroid, dan golongan tanin. Hasil pengujian disajikan selengkapnya pada Tabel 2 .

Tabel. 1 Rendamen Ekstrak Daun P.canencens

\begin{tabular}{lccc}
\hline No & Sampel & Berat (gram) & Keterangan \\
\hline 1 & Simplisia Kering & 1100 & Serbuk \\
2 & Ekstrak Metanol & 53,632 & Ekstrak Metanol \\
\hline
\end{tabular}

Tabel 2. Hasil uji metabolit sekunder ekstrak metanol daun P.canencens

\begin{tabular}{|c|c|c|c|c|c|c|c|c|}
\hline \multirow{3}{*}{ No } & \multirow{3}{*}{ Ekstrak } & \multicolumn{7}{|c|}{ Golongan Metabolit Sekunder } \\
\hline & & \multicolumn{2}{|c|}{ Alkaloid } & \multirow{2}{*}{$\begin{array}{c}\text { Terpenoid } \\
\text {-Steroid }\end{array}$} & \multicolumn{4}{|c|}{ Golongan Polifenol } \\
\hline & & Mayer & Dragendorf & & Flavanoid & Saponin & Tanin & Antosian \\
\hline 1 & Metanol & + & + & + & + & - & + & - \\
\hline
\end{tabular}

Keterangan : + : Positif terdeteksi metabolit sekunder

- : Negatif tidak terdeteksi metabolit sekunder 
Identifikasi metabolit sekunder dan aktivitas antibakteri ekstrak daun sungkai (Peronema canescens jack.) Terhadap beberapa bakteri patogen

\section{Aktivitas Antibakteri (Nilai Kadar Hambat Minimum)}

\section{a) Metode dilusi cair}

Uji Kadar Hambat Minimum (KHM) dengan metode dilusi cair dilakukan terhadap 4 macam bakteri uji yaitu bakteri St.mutans, S.thyposa, B.subtilis dan S.aureus dengan konsentrasi uji berturutturut adalah $5 \%, 10 \%, 15 \%, 20 \%$ dan $25 \%$. Hasil pengujian KHM dapat dilihat pada Tabel 3.
Hasil uji Kadar Hambat Minimal (KHM) ekstrak pada Tabel 3. menunjukkan bahwa pada KHM masing-masing bakteri uji adalah konsentrasi $10 \%$ untuk S.mutans, konsentrasi $15 \%$ untuk S. thyposa, B.subtilis, dan konsentrasi $20 \%$ untuk S.aureus. Gambar grafik KHM ekstrak metanol daun Sungkai terhadap masingmasing bakteri uji dapat dilihat pada Gambar 1.

Tabel 3. Hasil uji KHM ekstrak metanol daun P.canencens terhadap bakteri uji

\begin{tabular}{|c|c|c|c|c|c|c|c|c|c|c|c|}
\hline \multirow{3}{*}{ No } & \multirow{3}{*}{ Ekstrak } & \multicolumn{10}{|c|}{ Bakteri uji dan Konsentrasi uji (\%) } \\
\hline & & \multicolumn{5}{|c|}{ Streptococcus mutans } & \multicolumn{5}{|c|}{ Salmonella thyposa } \\
\hline & & 25 & 20 & 15 & 10 & 5 & 25 & 20 & 15 & 10 & 5 \\
\hline \multirow{4}{*}{1} & \multirow{4}{*}{ Metanol } & + & + & + & + & - & + & + & + & - & - \\
\hline & & \multicolumn{5}{|c|}{ Bacillus subtilis } & \multicolumn{5}{|c|}{ Staphylococcus aureus } \\
\hline & & 25 & 20 & 15 & 10 & 5 & 25 & 20 & 15 & 10 & 5 \\
\hline & & + & + & + & - & - & + & + & - & - & - \\
\hline
\end{tabular}

\section{Keterangan:}

(+) $\quad$ : medium bening, menandakan tidak terdapat pertumbuhan bakteri uji ekstrak uji

(-) : : medium keruh, menandakan terdapat pertumbuhan bakteri uji

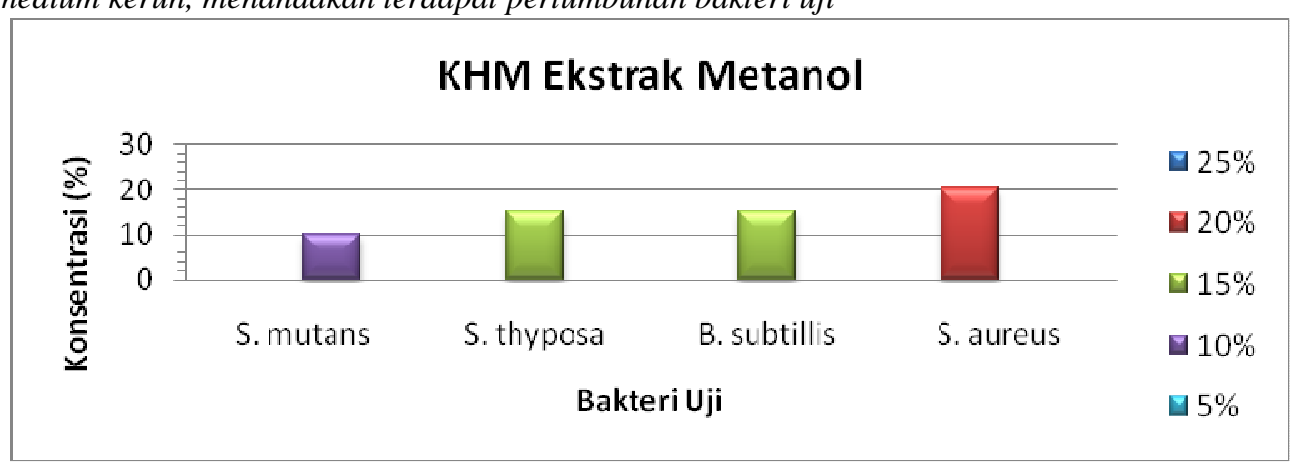

Gambar 1. Grafik hasil uji KHM ektrak metanol daun P.canencens terhadap masing-masing bakteri uji

\section{b) Metode dilusi padat}

Setelah dilakukan uji Kadar Hambat Minimum (KHM) metode dilusi cair selanjutnya dilakukan uji penentuan Kadar Hambat Minimum (KHM) dengan metode dilusi padat yaitu dengan cara menggoreskan masing-masing 1 ose di atas permukaan agar padat Nutrien Agar untuk masing-masing konsentrasi uji dari tabung pengujian Kadar Hambat Minimum (KHM) metode dilusi cair yang telah diinokulasikan 4 macam bakteri uji yaitu $S$. mutans, S.thyposa, B.subtilis dan S.aureus dengan konsentrasi uji berturut-turut adalah $25 \%, 20 \%, 15 \%, 10 \%$, dan 5\%. Hasil 
Identifikasi metabolit sekunder dan aktivitas antibakteri ekstrak daun sungkai (Peronema canescens jack.) Terhadap beberapa bakteri patogen

pengujian KHM metode dilusi padat dapat dilihat pada Tabel 4 .

Hasil uji Kadar Hambat Minimum (KHM) ekstrak pada Tabel 4. menunjukkan bahwa aktifitas ekstrak metanol terhadap seluruh bakteri uji tidak memberikan aktifitas daya bunuh akan tetapi hanya memberikan efek daya hambat pertumbuhan bakteri pada medium agar padat NA. Konsentrasi $20 \%$ ekstrak metanol aktif menghambat pertumbuhan bakteri S.mutans, S. thyposa dan S.aureus, sedangkan konsentrasi $15 \%$ aktif menghambat bakteri $B$. subtilis. Grafik Kadar Hambat Minimum (KHM) hasil dilusi padat ekstrak metanol terhadap masing-masing bakteri uji dapat dilihat pada Gambar 2.

Tabel 4. Hasil uji KBM ekstrak metanol daun P.canencens terhadap bakteri uji

\begin{tabular}{|c|c|c|c|c|c|c|c|c|c|c|c|}
\hline \multirow{3}{*}{ No } & \multirow{3}{*}{ Ekstrak } & \multicolumn{10}{|c|}{ Bakteri uji dan Konsentrasi uji (\%) } \\
\hline & & \multicolumn{5}{|c|}{ Streptococcus mutans } & \multicolumn{5}{|c|}{ Salmonella thyposa } \\
\hline & & 25 & 20 & 15 & 10 & 5 & 25 & 20 & 15 & 10 & 5 \\
\hline \multirow{4}{*}{1} & \multirow{4}{*}{ Metanol } & $+/-$ & $+/-$ & - & - & - & $+/-$ & $+/-$ & - & - & - \\
\hline & & \multicolumn{5}{|c|}{ Bacillus subtilis } & \multicolumn{5}{|c|}{ Staphylococcus aureus } \\
\hline & & 25 & 20 & 15 & 10 & 5 & 25 & 20 & 15 & 10 & 5 \\
\hline & & $+/-$ & $+/-$ & $+/-$ & - & - & $+/-$ & $+/-$ & - & - & - \\
\hline
\end{tabular}

Keterangan:

(+) : : medium bening, menandakan daya bunuh tanpa koloni mikroba uji

$(+/-)$ : medium keruh, menandakan zona penghambatan pertumbuhan mikroba uji

(-) : : medium ditumbuhi koloni bakteri, menandakan terjadi pertumbuhan bakteri uji

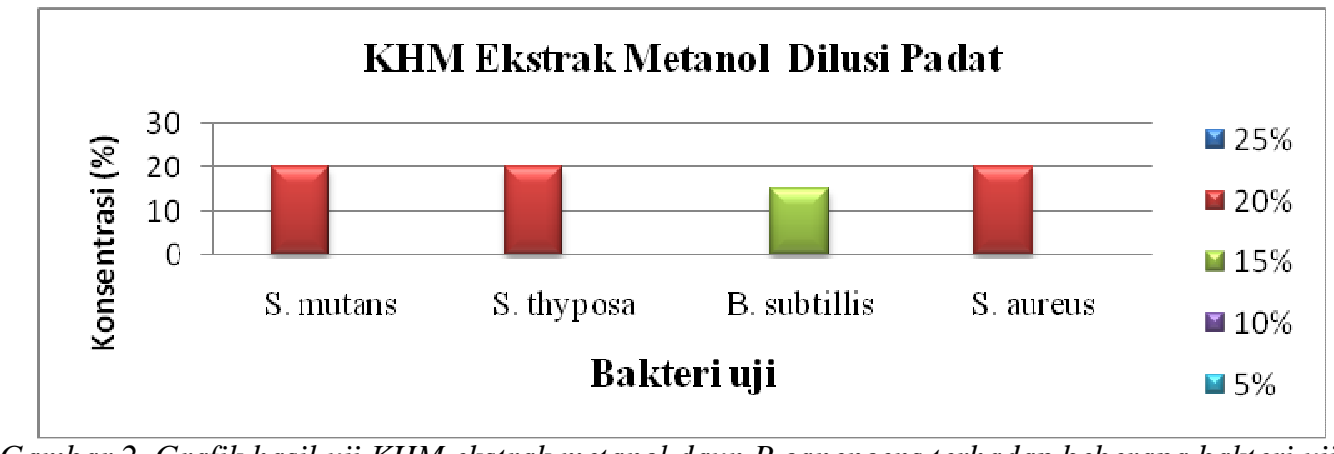

Gambar 2. Grafik hasil uji KHM ekstrak metanol daun P.canencens terhadap beberapa bakteri uji

\section{Aktivitas Antibakteri (Nilai Kadar Bunuh Minimum)}

Kadar Bunuh Minimum (KBM) dengan metode difusi agar menggunakan kertas saring yang sebelumnya telah direndam ke dalam larutan ekstrak selama kurang lebih 30 menit, selanjutnya kertas saring diletakkan di atas permukaan medium agar NA padat yang telah diinokulasikan bakteri uji dan diinkubasi pada suhu $37^{\circ} \mathrm{C}$ selama 1 x 24 jam dalam inkubator. Pengamatan kadar bunuh ekstrak berdasarkan zona bening yang dihasilkan disekitar kertas saring. Konsentrasi ekstrak metanol yang digunakan dalam pengujian Kadar Bunuh Minimum (KBM) dalam penelitian ini terdiri atas lima variasi konsentrasi yaitu konsentrasi $20 \%, 15 \%, 10 \%, 5 \%$ dan $1 \%$, dengan 4 macam jenis bakteri uji yaitu $S$. mutans, S. thyposa, B. subtilis dan $S$. aureus. Hasil pengujian dinyatakan memberikan aktifitas pembunuhan bakteri ditunjukkan dengan terbentuknya zona bening disekeliling kertas saring, selanjutnya diukur diameter zona 
Identifikasi metabolit sekunder dan aktivitas antibakteri ekstrak daun sungkai (Peronema canescens jack.) Terhadap beberapa bakteri patogen

bunuhnya. Konsentrasi terkecil dari ekstrak uji yang mampu membunuh/menghambat pertumbuhan bakteri dinyatakan sebagai Kadar Bunuh Minimal (KBM) ekstrak.
Hasil pengukuran zona bening atau zona bunuh masing-masing konsentrasi ekstrak metanol daun Sungkai dapat dilihat pada Tabel 5 .

Tabel 5. Hasil pengukuran zona bening atau zona bunuh masing-masing konsentrasi ekstrak terhadap bakteri S. mutans

\begin{tabular}{cccccccc}
\hline No & Mikroba Uji & $\begin{array}{c}\text { Konsent } \\
\text { rasi }\end{array}$ & \multicolumn{4}{c}{$\begin{array}{c}\text { Diameter zona hambat } \\
\text { ekstrak metanol (mm) }\end{array}$} \\
\hline & & & $\mathrm{n} 1$ & $\mathrm{n} 2$ & $\mathrm{n} 3$ & Jumlah & Rata-rata \\
\cline { 3 - 7 } & $\mathbf{1 \%}$ & 0 & 0 & 0 & 0 & $\mathbf{0}$ \\
\multirow{4}{*}{1} & Streptococcus & $\mathbf{5 \%}$ & 3,42 & 4,45 & 4,15 & 12,02 & $\mathbf{4 , 0 1}$ \\
& mutans & $\mathbf{1 0 \%}$ & 5,87 & 4,60 & 4,93 & 15,4 & $\mathbf{5 , 1 3}$ \\
& & $\mathbf{1 5 \%}$ & 6,65 & 6,67 & 7,19 & 20,51 & $\mathbf{6 , 8 4}$ \\
& $\mathbf{2 0 \%}$ & 15,29 & 14,11 & 13,34 & 42,74 & $\mathbf{1 4 , 2 5}$ \\
\hline
\end{tabular}

Tabel 6. Hasil pengukuran zona bening atau zona bunuh masing-masing konsentrasi ekstrak terhadap bakteri S. thyposa

\begin{tabular}{lccccccc}
\hline \multirow{2}{*}{ No } & \multirow{2}{*}{$\begin{array}{c}\text { Konsent } \\
\text { Mikroba Uji }\end{array}$} & \multicolumn{5}{c}{$\begin{array}{c}\text { Diameter zona hambat } \\
\text { ekstrak metanol (mm) }\end{array}$} \\
\cline { 3 - 7 } & & rasi & $\mathrm{n} 1$ & $\mathrm{n} 2$ & $\mathrm{n} 3$ & Jumlah & Rata-rata \\
\hline & & $\mathbf{1 \%}$ & 0 & 0 & 0 & 0 & $\mathbf{0}$ \\
& & $\mathbf{5 \%}$ & 6,47 & 4,43 & 5,27 & 16,17 & $\mathbf{5 , 3 9}$ \\
$\mathbf{2}$ & Salmonella & $\mathbf{1 0 \%}$ & 5,89 & 5,56 & 6,12 & 17,57 & $\mathbf{5 , 8 6}$ \\
& thyposa & $\mathbf{1 5 \%}$ & 6,35 & 6,11 & 6,87 & 19,33 & $\mathbf{6 , 4 4}$ \\
& & $\mathbf{2 0 \%}$ & 6,74 & 6,42 & 6,37 & 19,53 & $\mathbf{6 , 5 1}$ \\
\hline
\end{tabular}

Tabel 7. Hasil pengukuran zona bening atau zona bunuh masing-masing konsentrasi ekstrak terhadap bakteri B. subtilis

\begin{tabular}{cccccccc}
\hline \multirow{2}{*}{ No } & Mikroba Uji & $\begin{array}{c}\text { Konsent } \\
\text { rasi }\end{array}$ & \multicolumn{4}{c}{$\begin{array}{c}\text { Diameter zona hambat } \\
\text { ekstrak metanol (mm) }\end{array}$} \\
\hline \multirow{4}{*}{} & & $\mathrm{n} 1$ & $\mathrm{n} 2$ & $\mathrm{n} 3$ & Jumlah & Rata-rata \\
\cline { 3 - 7 } & & $\mathbf{1 \%}$ & 3,53 & 5,16 & 4,75 & 13,44 & $\mathbf{4 , 4 8}$ \\
& & $\mathbf{5 \%}$ & 3,21 & 2,75 & 3,10 & 9,06 & $\mathbf{3 , 0 2}$ \\
& \multirow{3}{*}{ Basillus subtilis } & $\mathbf{1 0 \%}$ & 3,27 & 2,99 & 2,64 & 8,90 & $\mathbf{2 , 9 7}$ \\
& & $\mathbf{1 5 \%}$ & 7,65 & 6,24 & 5,98 & 19,87 & $\mathbf{6 , 6 2}$ \\
& & $\mathbf{2 0 \%}$ & 10,32 & 9,71 & 9,65 & 29,68 & $\mathbf{9 , 8 9}$ \\
\hline
\end{tabular}

Tabel 8. Hasil pengukuran zona bening atau zona bunuh masing-masing konsentrasi ekstrak terhadap bakteri S. aureus

\begin{tabular}{cccccccc}
\hline No & Mikroba Uji & $\begin{array}{c}\text { Konsent } \\
\text { rasi }\end{array}$ & \multicolumn{4}{c}{$\begin{array}{c}\text { Diameter zona hambat } \\
\text { ekstrak metanol (mm) }\end{array}$} \\
\hline & & & $\mathrm{n} 1$ & $\mathrm{n} 2$ & $\mathrm{n} 3$ & Jumlah & Rata-rata \\
\hline & & $\mathbf{1 \%}$ & 1,01 & 1,63 & 1,17 & 3,81 & $\mathbf{1 , 2 7}$ \\
\multirow{4}{*}{4} & $\mathbf{5 \%}$ & 2,30 & 2,53 & 3,05 & 7,88 & $\mathbf{2 , 6 3}$ \\
& Stapilococcus & $\mathbf{1 0 \%}$ & 2,64 & 3,45 & 2,87 & 8,96 & $\mathbf{2 , 9 9}$ \\
& aureus & $\mathbf{1 5 \%}$ & 8,51 & 8,46 & 8,40 & 25,37 & $\mathbf{8 , 4 6}$ \\
& & $\mathbf{2 0 \%}$ & 10,40 & 9,85 & 9,10 & 29,35 & $\mathbf{9 , 7 8}$ \\
\hline & Kontrol air & $\mathbf{0 \%}$ & 0 & 0 & 0 & 0 & $\mathbf{0}$ \\
\hline
\end{tabular}


Identifikasi metabolit sekunder dan aktivitas antibakteri ekstrak daun sungkai (Peronema canescens jack.) Terhadap beberapa bakteri patogen

Data pada Tabel 5, 6, 7, dan 8 . menunjukkan bahwa ekstrak metanol daun Sungkai memiliki aktivitas sebagai antibakteri. Penggunaan kontrol negatif air bertujuan untuk memastikan bahwa zona bunuh yang terbentuk bukan pengaruh dari pelarut air, akan tetapi zona bunuh yang terbentuk murni dari kandungan senyawa aktif yang terdapat dalam ekstrak kasar metanol daun Sungkai. Berdasarkan diameter zona bunuh pada Tabel 4.5 terlihat konsentrasi ekstrak uji terkecil yang masih memberikan aktifitas pembunuhan terhadap bakteri uji berdasarkan zona bening (KBM) adalah untuk bakteri

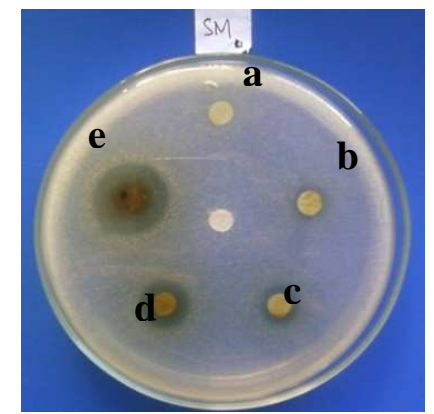

A

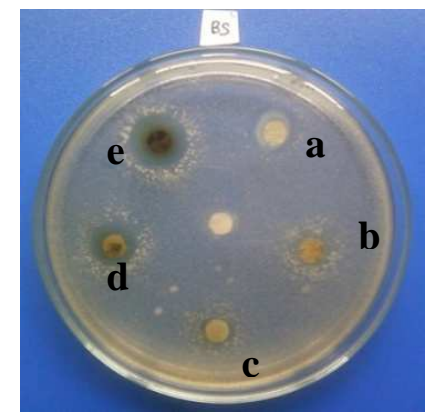

C
Streptococcus mutans dan bakteri Salmonela thyposa efektif membunuh pada konsentrasi 5\%, terhadap bakteri Basillus subtilis dan Staphylococcus aureus efektif membunuh pada konsentrasi $1 \%$. Gambar hasil uji KBM dengan metode difusi agar ekstrak metanol terhadap masing-masing bakteri uji dapat dilihat pada Gambar 4.

Grafik Kadar Bunuh Minimum (KBM) ekstrak metanol masing masing bakteri uji berdasarkan diameter rata-rata terkecil zona bunuhnya dapat dilihat pada Gambar 5 .

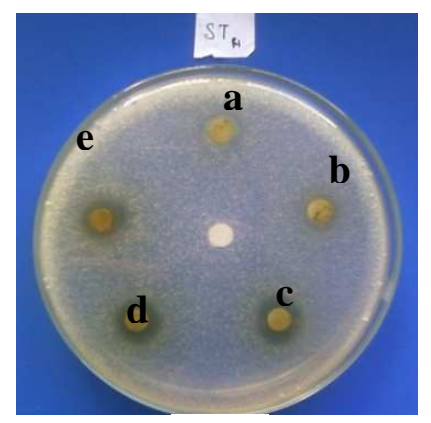

B

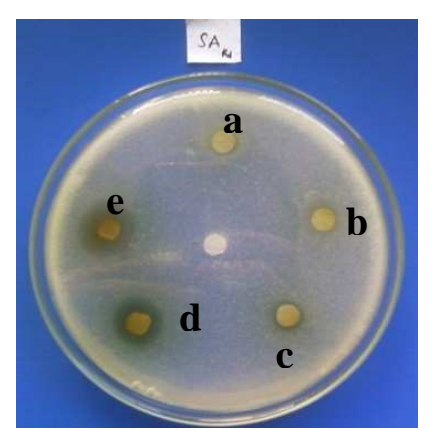

$\mathrm{D}$

Gambar 4. Gambar hasil uji Kadar Bunuh Minimal (KBM) ekstrak metanol daun Sungkai (Peronema canescens Jack.) terhadap bakteri : (A) Streptococcus mutans, (B) Salmonella thyposa, (C) Bacillus subtilis, dan (D)

Staphylococcus aureus

Keterangan :

(a). Konsentrasi 1\%; (b). Konsentrasi $5 \%$; (c). Konsentrasi 10\%; (d). Konsentrasi $15 \%$; (e).Konsentrasi 20\%; Medium uji : Nutrien agar (NA); Suhu Inkubasi : $37^{\circ} \mathrm{C}$, selama 1 × 24 jam 
Identifikasi metabolit sekunder dan aktivitas antibakteri ekstrak daun sungkai (Peronema canescens jack.) Terhadap beberapa bakteri patogen

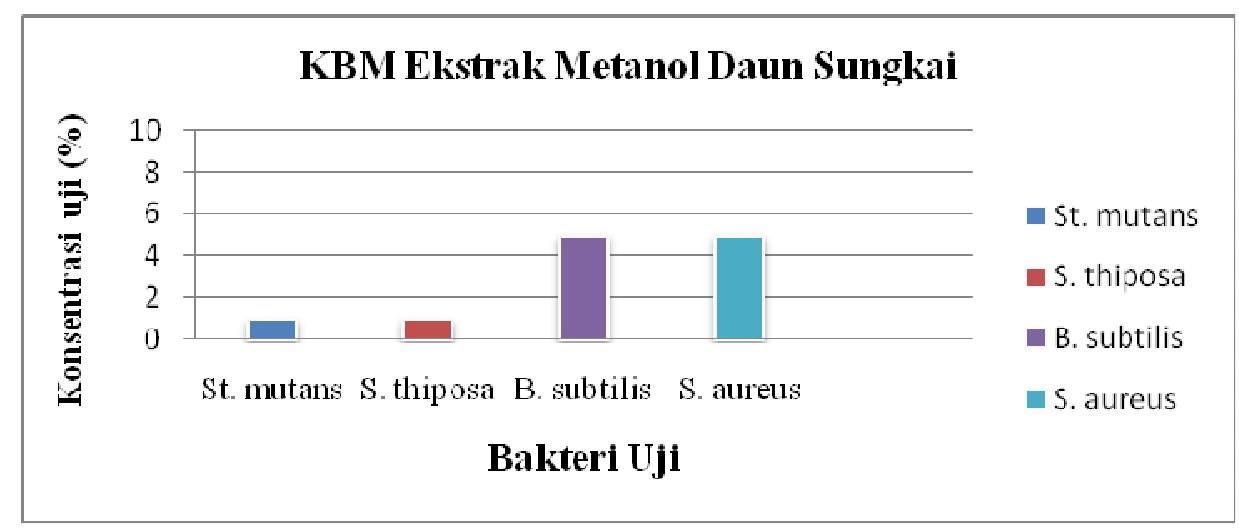

Gambar 5. Kadar Bunuh Minimum (KBM) ekstrak metanol masing masing bakteri uji berdasarkan diameter rata-rata terkecil zona bunuhnya

\section{Hubungan Aktifitas Antibakteri Metabolit Sekunder Ekstrak Metanol}

Mekanisme antibakteri dari senyawa metabolit sekunder pada dasarnya memiliki mekanisme berbeda-beda. Alkaloid memiliki kemampuan sebagai antibakteri. Mekanisme yang diduga adalah dengan cara mengganggu komponen penyusun peptidoglikan pada sel bakteri, sehingga lapisan dinding sel tidak terbentuk secara utuh dan menyebabkan kematian sel (Robinson, 1995).

Golongan senyawa terpenoid berpotensi sebagai antimikroba antara lain memiliki sifat antijamur, antibakteri dan antivirus. (Robinson, 1995). Mekanisme kerja sebagai antibakteri diduga bekerja merusak dinding sel bakteri dengan jalan mengganggu komponen petidoglikan sel bakteri sehingga lapisan dinding sel mengalami kerusakan menyebabkan isi sel keluar/ sel lisis dan bakteri mengalami kematian. (Robinson, 1995).

Golongan Flavonoid berfungsi sebagai antibakteri dengan cara membentuk senyawa kompleks terhadap protein ekstraseluler yang mengganggu integritas membran sel bakteri. Menurut
(Dwidjoseputro, 2005) flavanoid merupakan senyawa fenol, sementara senyawa fenol dapat bersifat koagulator protein.

Golongan senyawa polifenol merupakan kelompok terbesar dalam tumbuhan salah satunya adalah tanin yang memiliki aktivitas antibakteri, secara garis besar mekanisme yang diperkirakan yaitu toksisitas golongan senyawa polifenol dapat merusak membran sel bakteri. Menurut (Ajizah, 2004) tanin merupakan kelompok senyawa polifenol yang memiliki aktifitas antibakteri, mekanisme kerja tanin sebagai antibakteri diduga dapat mengkerutkan dinding sel atau membran sel sehingga mengganggu permeabilitas sel itu sendiri, akibat terganggunya permeabilitas, sel tidak dapat melakukan aktivitas hidup sehingga pertumbuhannya terhambat atau bahkan mati. (Masduki 1996) menyatakan bahwa tanin juga mempunyai daya antibakteri dengan cara mempresipitasi protein, karena diduga tanin mempunyai efek yang sama dengan senyawa fenolik. Efek antibakteri tanin antara lain melalui reaksi dengan membran sel, inaktivasi enzim, dan destruksi atau inaktivasi fungsi materi genetik. (Akiyama, dkk., 2001) 
Selain itu kemampuan senyawa antibakteri dalam menghambat pertumbuhan bakteri dipengaruhi oleh kestabilan terhadap protein, lipid, garam dan tingkat keasaman (pH) dalam medium pertumbuhan. Komposisi kimia penyusun sel bakteri gram positif terdiri atas lapisan mukopeptida atau peptidoglikan, lapisan ini bersifat non polar, sehingga molekul senyawa dengan sifat lipofilik akan lebih mudah menembus dinding sel bakteri melalui interaksi terhadap protein dan lapisan peptidoglikan menyebabkan kerusakan struktur dinding sel dan bakteri mengalami lisis dan akhirnya bakateri mengalami kematian. (Djide, 2008)

\section{KESIMPULAN}

Hasil penelitian identifikasi metabolit sekunder ekstrak diperoleh golongan senyawa alkaloid, terpenoid - steroid, flavanoid, dan tanin. Ekstrak metanol daun $P$. canencens Jack. memiliki aktivitas sebagai antibakteri. Nilai KHM ekstrak metanol daun $P$. canencens untuk bakteri S.mutans, S.thyposa dan S.aureus adalah konsentrasi $20 \%$, sedangkan untuk $B$. subtilis adalah $15 \%$. Nilai KBM ekstrak metanol $P$. canencens pada konsentrasi 5\% efektif membunuh bakteri Str. mutans dan S. thyposa, sedangkan konsentrasi $1 \%$ efektif membunuh bakteri B.subtilis dan S.aureus.

\section{UCAPAN TERIMA KASIH}

Ucapan terima kasih kepada Universitas Mulawarman yang telah memberikan dana penelitian dan kepada Lembaga Penelitian Unmul yang telah menerima proposal penelitian sebagai salah satu yang dinyatakan lolos seleksi penelitian Dosen Pemula tahun 2012, kepada ketua UP. Fakultas Farmasi Unmul dan kepala Laboratorium Biologi dan Mikrobiologi dan Laboratorium Bahan Alam UP. J. Trop. Pharm. Chem. 2012. Vol 1. No. 4.
Fakultas Farmasi UNMUL yang telah memberikan izin menggunakan laboratorium untuk penelitian. Kepada laboran dan teknisi laboratorium serta mahasiswa yang ikut membantu dalam penelitian ini.

\section{DAFTAR PUSTAKA}

1. Ajizah, A. 2004. Sensitivitas Salmonella Typhimurium Terhadap Ekstrak Daun Psidium Guajava L. Bioscientiae, Vol.1, No.1 : 31-8

2. Akiyama, H., Fuji., Yamasaki., dkk., 2001., Antibacterial Action of Several Tannins Agains Staphylococcus aureus., Journal of Antimicrobia Cahemotherapy. Vol. 48 : 487-91.

3. Chamber, H.F. 2001. goodman an Gilman's The Pharmacological Basis of Therapeutics dalam Handman and Limbird (Eds), Antimicrobial agents (1143-1169). USA: McGraw-Hill Companies Inc.

4. Departemen Kesehatan Republik Indonesia, 2000, Parameter Standar Umum Ekstrak Tumbuhan Obat, Departemen Kesehatan RI. Jakarta

5. Djide, N, \& Sartini. 2008. Analisis Mikrrobiologi Farmasi. Universitas Hasanuddin; Makassar

6. Dwidjoseputro. 2005. Dasar-Dasar Mikrobiologi. Djambaran; Jakarta.

7. Hertiani,T., Palupi, S.I., Sanliferianti, dan Nurwindasari, D.H., 2003, Uji Invitro Antimikroba Terhadap Staphylococus aureus, Eschericia coli, Shygella dysentriae dan Candida albicans Dari Beberapa Tanaman Obat Tradisional Untuk Penyakit Infeksi. Jurnal Farmasi Indonesia Pharmacon. Volume 4 (2), Desember 2003. 89-95

8. Jawetz, Melnick \& Adelber. 2005. Mikrobiologi kedokteran (Buku 1), Diterjemahkan oleh Penerjemah Bagian Mikrobiologi Fakultas Kedokteran 
Universitas Airlangga. Salemba Medika; Surabaya.

9. Mardi. 2010. Koleksi Herba Institut Penyelidikan dan Kemajuan Pertanian Malaysia. (Online). http://wannura.wordpress.com). diakses tanggal 12 Juni 2011

10. Masduki I, 1996. Efek Antibakteri Ekstrak Biji Pinang (Areca catechu) terhadap S. aureus dan E. coli. Cermin Dunia Kedokteran 109: 21-4
11. Padmawinata.K., dan I. Soediro. 2006. Metode Fitokimia Penuntun Cara Modern Menganalisis Tumbuhan. ITB .Bandung

12. Robinson T. 1995, Kandungan Organik Tumbuhan Tingkat Tinggi, ITB, Bandung

13. Sinambela, J.M. 2002. Pemanfaatan Plasma Nutfah dalam Industri Jamu dan Kosmetika Alami. Buletin Plasma Nutfah 